\title{
УДК: $355.23(477): 378.5$
}

\author{
Олександр Віталійович Левченко (доктор військових наук, професор) \\ Дмитро Леонідовцч Федорчук (кандидат технічних наук) \\ Юрій Іванович Міхєєв (кандидат технічних наук)
}

Житомирський військовий інституту імені С.П. Корольова, Житомир, Украӥна

\section{АНАЛІЗ ОСНОВНИХ ЗАГРОЗ НАЦІОНАЛЬНІЙ БЕЗПЕЦІ ДЕРЖАВ- СУСІДІВ УКРАЇНИ В УМОВАХ ГІБРИДНОЇ АГРЕСІї РОСІї}

У статті розглянуто поняття та сутність загроз національній безпеці держав-сусідів Украӥни, спричинених гібридною агресією Російської Федераиії. Проаналізовано нормативно-правові акти, які визначають можслиі інформаційні загрози для України та держави-сусідів: Польщі, Словаччини, Румунії, Молдови, Угорщиини, Білорусі. Основну увагу приділено реальним та потенційним загрозам національній безпеці держави в інформаційній сфері, а саме намаганню маніпулювати суспільною свідомістю, зокрема иляхом поширення пропагандистських повідомлень, недостовірної, неповної або упередженої інформації. Розглянуто Стратегію національної безпеки Російської Федерації, яка визначає причини виникнення загроз національній безпеці держави.

На основі аналізу результатів моніторингу інформаційного простору визначено основну изільову аудиторію, обрану спецслужбами Російської Федерації для поширення пропагандистських повідомлень. При иььому враховано основні иілі пропаганди, яка поширювалася спецслужбами Російської Федерації під час проведення антитерористичної операчії та поширюється в умовах проведення операчії Об'єднаних сил з метою досягнення стратегічних иүілей держави-агресора, а саме: дискредитації держави на міжнародній арені, підриву довіри до неї як до надійного економічного та політичного партнера; дискредитації військово-політичного керівництва держави, керівників органів державної влади усіх рівнів серед українського суспільства; дестабілізації внутрішньополітичної обстановки в державі; зниження морально-психологічного стану особового складу Збройних Сил Украӥни; інформаційної підтримки керівництва тимчасово окупованих територій, ватажків незаконно створених збройних формувань, терористичних організацій так званих “ДНР” та “ЛНР”; демонстрації військової могутності Російської Федераиіiі.

За результатами проведеного аналізу задекларованих національних інтересів та загроз національній безпечі держав-сусідів України з'ясовано особливості конфронтації національних інтересів нашої держави: етнічне розмаїття суспільства, ескалація напруженості в зоні територіальних інтересів, агресія Російської Федераиії.

Ключові слова: гібридна агресія, наџіональні інтереси, наџіональна безпека держави, пропаганда, Російська Федерація, держави-сусіди, моніторинг інформаційного простору.

\section{Вступ}

У сучасній геополітиці під національними інтересами (НI) розуміють стратегічно важливі цілі, які ставить перед собою кожна держава, і засоби, за допомогою яких вона їх досягає [1]. Однією 3 пріоритетних серед таких цілей є забезпечення інформаційної та кібернетичної безпеки держави як стану захищеності життєво важливих інтересів людини і громадянина, суспільства та держави в кіберпросторі, що досягається комплексним застосуванням сукупності правових, організаційних та інформаційних заходів [2]. Особливо питання забезпечення інформаційної та кібернетичної безпеки держави зростає, коли проявляються елементи гібридизації - не нові за сутністю але унікальні за узгодженістю цілей, динамічністю їх досягнення, зростанням ролі інформаційної та кібернетичної складової на усіх рівнях [3].

Постановка проблеми. Відповідно до Стратегії воєнної безпеки України [4] визначено, що агресивна зовнішня і воєнна політика Російської Федерації (РФ) загрожує національній безпеці України та інших держав Балтійського i Чорноморського регіонів, може призвести до подальшої ескалації збройної агресії проти України та спровокувати міжнародний збройний конфлікт у Європі. На національному рівні РФ залишається воєнним противником України, який здійснює збройну агресію проти України, тимчасово окупував територію Автономної Республіки Крим та міста Севастополь, території у Донецькій та Луганській областях, системно застосовує воєнні, політичні, економічні, інформаційно-психологічні, космічні, кібер- та інші засоби, що загрожують незалежності, державному суверенітету i територіальній цілісності України. Для реалізації державної політики у воєнній сфері передбачається створення системи комплексного стратегічного аналізу воєнних загроз національній безпеці України. 
Географічно Україна межує по суходолу із сімома державами, які, виходячи 3 їх задекларованих законодавчо НІ, можна умовно поділити на дві групи: держави проєвропейського спрямування та держави проросійського спрямування. До першої групи відносимо Польщу, Словаччину, Румунію, Молдову, Угорщину; до другої - Білорусь і, власне, Росію. Для розуміння точок розходження інтересів України, a, отже, i потенційних цілей пропаганди проти нашої держави, 3 інтересами держав-сусідів необхідно проаналізувати послідовно їх НІ, геостратегічні цілі та основні загрози НБ.

Аналіз останніх досліджень і публікацій. Аналіз наукових досліджень за тематикою свідчить про те, що у своїх публікаціях автори розглядають тільки деякі сфери забезпечення національної безпеки окремої держави, які спричинені різними факторами (загрозами), у тому числі, й гібридною агресією Росії проти України [5-8]. Так, у [5] на основі аналізу перебігу процесів анексії РФ Автономної Республіки Крим та сучасних збройних конфліктів авторами визначено особливості прояву інформаційних загроз та їх розвиток у воєнній сфері.

У [6] автором розглянуто передумови та причини розроблення керівництвом Республіки Польща нової редакції Стратегії національно безпеки. Особливу увагу приділено оцінці безпекового середовища Республіки Польща, загроз і викликів, що стоять перед країною та Європейським регіоном.

У [7] автор розглядає вплив російської агресії проти України на зовнішню політику і національну безпеку Румунії. Визначені основні загрози й ризики, а також ключові напрями політики Бухареста за для їх мінімізації і посилення своєї ролі на східному фланзі НАТО та СС і в ареалі регіону Чорного моря. Ключовими загрозами визначаються загроза енергетичній сфері та кібербезпеці.

У [8] визначено засади та здійснено поелементний аналіз національної безпеки Республіки Білорусь. Аналізуються фактори, що справляють як безпосередній, так i опосередкований вплив на національну безпеку країни. Акцентується увага на появі нових загроз у інформаційній сфері.

3 огляду на це, виникає необхідність у визначенні основних загроз національній безпеці України 3 боку держав-сусідів. Тому обраний напрям досліджень $є$ актуальним.

Метою статті $\epsilon$ дослідження умов появи основних загроз національній безпеці державсусідів України, що спричинені гібридною агресією Росії проти України.

\section{Виклад основного матеріалу дослідження}

Проєвропейська спрямованість напрямів розвитку першої групи держав визначена у відповідних нормативно-правових та стратегічних документах у сфері національної безпеки (НБ) та оборони, що в загальному аргументується форматом їх участі в міжнародних системах колективної безпеки, інтеграційних процесах, пов'язаних 3 вступом до Європейського союзу, прагнення до енергетичної незалежності від Росії як найбільшого виробника та постачальника енергоносіїв у регіоні тощо.

Окрему увагу слід приділити деяким специфічним моментам, притаманним НІ держав, що розглядаються. Так, Словаччина та Угорщина наголошують на всебічній підтримці своїх етнічних меншин на територіях інших держав, проводячи послідовну, а подекуди й наполегливу (Угорщина) зовнішню політику, яка на сьогоднішній день уже призводить до певних непорозумінь, напруженостей як в України, так і в її відносинах із зазначеними державами. Яскравим прикладом пропагандистської інформаційної кампанії, основаної на реалізації НІ Угорщини, стала нещодавня критика щодо внесення змін до законодавства України про освіту [9].

Агресивні дії збоку РФ у 2014 році щодо України змусили проєвропейських сусідів переглянути власні переліки загроз НБ та оборони. Результатом стало внесення змін у існуючі нормативно-правові та стратегічні документи у сфері НБ. Усі вони мають декілька схожих положень. Отже, серед загроз НБ Польщі, Угорщини, Румунії, Словаччини та Молдови основними визначені такі:

експансія РФ поблизу кордонів;

конфлікти (зокрема, призупинені) у Чорноморському регіоні;

залежність енергетичної безпеки від РФ.

Причому, якщо Словаччина дипломатично формулює мілітарні дії РФ як “...головний виклик безпеці євроатлантичного простору” [10], то Польща відверто фіксує “...діï РФ щодо відновлення позицій наддержави за рахунок сусідів" [11].

Примітним $\epsilon$ визначення країнами Вишеградської четвірки (Польща, Словаччина, Угорщина, Чехія) серед основних завдань 3 забезпечення НБ: виявлення та моніторинг фактичних або потенційних викликів, ризиків та загроз у кіберпросторі; посилення захисту державних інформаційно-комунікаційних систем, національної критичної інформаційної інфраструктури, секретної інформації та національних інформаційних активів, а також посилення міжнародного співробітництва 3 кібербезпеки [12]. Причому на думку Угорського керівництва слід активно розвивати наступальні можливості відповідних підрозділів для кібернетичних операцій. Також наголошується на призупиненні військової співпраці з Росією. Але разом $з$ тим, Угорщина прагне зниження ризиків, викликаних напруженістю між НАТО та РФ та зацікавлена у прагматичному розвитку угорськоросійських відносин. Подібні побоювання опосередковано у свої Стратегіях і Доктринах висловлюють й інші проєвропейські держави [13-14], що, у свою чергу, сприяє проведенню 

Україною послідовної
інформаційної політики.

Якщо проєвропейські держави-сусіди України єдині у своєму тлумаченні дій РФ щодо України, що підкріплено відповідним супроводом в інформаційному полі, то проросійська Білорусь подекуди утримується від різких заяв та на офіційному рівні не визнає цієї агресії. Керівництво Республіки у своїй Концепції національної безпеки, яка не зазнала змін з 2010 року, серед основних НІ держави в воєнній сфері визначає “послідовний розвиток та зміцнення воєнного та воєннотехнічного співробітництва 3 РФ” [15]. Білорусь позиціонує себе на міжнародній арені незалежною державою, яка тримає нейтралітет на тлі конфлікту Україна - РФ, виступаючи в деякому сенсі дипломатичним представником між конфліктуючими державами, надаючи майданчик для переговорів у форматі Нормандської четвірки. Такі дії Білорусі не суперечать іiі НІ та всебічно підтримуються інформаційними кампаніями, де гарантом достовірності заявлених напрямів співпраці виступає глава держави [16]. Проте, як показує аналіз новинних повідомлень у засобах масової інформації, у таких заявах мають місце певні маніпулювання фактами, де миролюбні заяви “дружньої” сусідньої держави вступають у протиріччя з діями щодо надання можливостей РФ 3 нарощування воєнної присутності на своїй території поблизу кордонів нашої держави [17]. Зважаючи на поступове та неухильне слідування заявленим НІ Республіки Білорусь, ця держава є потенційним противником України в інформаційному просторі як ретранслятор наративів Росії. Зважаючи на таке, ймовірними цілями пропаганди з боку цієї держави можуть бути:

підтримка російської інформаційної політики;

приховування воєнної активності збройних сил

(3С) РФ на своїй території поблизу кордонів 3 Україною;

створення враження нейтральної позиції щодо конфлікту РФ - Україна, РФ - НАТО.

Останнє потребує особливої уваги 3 боку України в розрізі завдань із забезпечення заявлених НІ та стратегічних національних пріоритетів РФ, серед яких зазначено $[18,19]$ :

розвиток інформаційних, комунікативних та когнітивних технологій;

застосування інформаційних технологій в інтересах збереження культурних, історичних та духовно-моральних

багатонаціонального народу РФ;

удосконалення форм і способів застосування 3С РФ 3 врахуванням тенденцій змін характеру сучасних війн і збройних конфліктів;

розвиток інтеграційних процесів на пострадянському просторі та засобів задоволення мовних та культурних потреб співвітчизників за кордоном шляхом реалізації програм підтримки вивчення російської мови та культури в Співдружності Незалежних Держав.

У той же час, серед загроз НБ Росії визначено: поширена практика повалення легітимних політичних режимів, провокування внутрішньодержавних нестабільності і конфліктів, особливо поблизу кордонів РФ;

прагнення деяких держав використовувати інформаційні та комунікаційні технології для досягнення своїх геополітичних цілей, зокрема шляхом маніпулювання суспільною свідомістю і фальсифікацією історії;

спроби інших держав щодо протидії Росії як центру впливу в світі, та послаблення ії позицій;

розвиток озброєнь у сусідніх державах.

Ці пункти, зафіксовані на рівні законодавства, стали основою для провадження агресивної інформаційної політики РФ на міжнародному рівні та щодо України.

Крім того, РФ визначає як негативний вплив на реалізацію НІ “...позицію Заходу, спрямовану на протидію інтеграційним процесам і створення вогнищ напруженості в Свразійському регіоні...” [19]. Загрозою НБ - “підтримка США і Європейським союзом антиконституційного державного перевороту в Україні”. Факторами виникнення нестабільності в Україні визначені “зміцнення ультраправої націоналістичної ідеології, цілеспрямоване формування в українського населення образу ворога в особі Росії, неприкрита ставка на силове вирішення внутрішньодержавних протиріч, глибока соціально-економічна криза".

Україна визначена як “...довгострокове вогнище нестабільності в Свропі і безпосередньо біля кордонів Росіі...", а Росія при цьому “...зберігає прихильність використанню, насамперед, політичних і правових інструментів, механізмів дипломатії i миротворчості. Застосування військової сили для захисту НІ можливо тільки в тому разі, якщо всі вжиті заходи ненасильницького характеру виявилися неефективними...” [19].

Аналіз загроз інформаційній безпеці табл.1 свідчить про наявність у кожному джерелі воєнної складової, яка формує джерело загрози інформаційній безпеці у воєнній сфері.

Таблиця 1

Загрози інформаційній безпеці

Зовнішні джерела загроз інформаційної безпеки

Вплив технічних засобів іноземної розвідки на політичні, економічні, військові структури

Концепції окремих держав щодо інформаційної та психологічної війни

Міжнародні терористичні організації та комп'ютерна злочинність

Міжнародна конкуренція за володіння

інформаційними ресурсами й технологіями

Ініціювання порушення інформаційної сфери на території противника

Порівнюючи воєнну та інформаційну сферу можна окреслити варіанти джерел загроз інформаційній безпеці у воєнній сфері: дискредитація органів управління; провокування 
сутичок між органами управління воєнної організації держави; утруднення прийняття органами управління воєнної організації держави важливих рішень; підрив авторитету воєнної організації держави; нанесення втрат життєво важливим інтересам держави в оборонній сфері.

Для запобігання таких загроз та досягнення стратегічних цілей керівництво РФ використовує відповідні спецслужби, які поширюють пропагандистські повідомлення в інформаційному просторі. Аналіз результатів моніторингу інформаційного простору свідчить про те, що основною цільовою аудиторією для пропагандистських повідомлень РФ проти України виступають:

політичне керівництво та населення України на підконтрольних територіях;

керівництво та особовий склад 3С України;

населення та військові формування на

окупованих територіях;

населення РФ;

міжнародна спільнота.

Як засіб маніпуляції суспільною свідомістю РФ використовує різні технології пропаганди, основними цілями якої $є$ :

дискредитація держави на міжнародній арені, підрив довіри до неї як до надійного економічного та політичного партнера;

дискредитація політичного керівництва держави, керівників органів державної влади державного та регіонального рівнів серед українського суспільства;

дестабілізація

обстановки в Україні;

дискредитація та зниження довіри до військового керівництва серед особового складу ЗС України та населення прилеглих до лінії розмежування територій та всередині держави, створення негативного образу українського воїна;

зниження морально-психологічного стану особового складу ЗС України;

зниження боєздатності частин і підрозділів через підбурювання до внутрішніх конфліктів та розколу військових колективів за політичними, релігійними, етнічними, службовими та іншими мотивами;

формування спотвореного сприйняття військовослужбовцями ЗС України наявних загроз НБ, справжніх планів і намірів противника.

інформаційна підтримка окупаційної влади на території анексованої АР Крим, керівників

\section{Jimepamypa}

1. Горбулін В. П. Пріоритетність національних інтересів у світлі національної безпеки України / Горбулін В. П., Качинський А. В. // Стратегічна панорама. - 2005. - № 3. - С. 11-18. 2. Закон України "Про основні засади забезпечення кібербезпеки України” від 05.10.2017 № 2163-VIII. URL: https://zakon.rada.gov.ua/laws/show/216319\#Text. 3. Грищук Р. В. Інформаційна та кібернетична безпека: роль та місце в умовах гібридної війни / Р.В. Грищук // Кібербезпека в Україні: правові та організаційні питання. URL:http://oduvs.edu.ua/wpcontent/uploads/2017/01/Hryshchuk R.V. Informatsiyna ta терористичних організацій “ДНР” та “ЛНР”, ватажків незаконних збройних формувань, героїзація терористів та окупаційних військ на непідконтрольних Україні територіях та серед населення РФ;

спотворене подання ситуації в Україні серед населення РФ задля утвердження думки щодо правильності дій воєнно-політичного керівництва Pociï;

демонстрація військової могутності ЗС РФ.

\section{Висновки і перспективи подальших досліджень}

Отже, проведений аналіз задекларованих державами-сусідами України НI та загроз НБ показав, що конфронтація нашої держави можлива за такими напрямами:

етнічне розмаїття суспільства (національні меншини через пропаганду в електронних засобах масової інформації та соціальних мережах можуть підбурюватися до порушення територіальної цілісності держави);

нестабільність у Чорноморському регіоні (деякі держави можуть використовувати маніпулятивні впливи задля ескалації напруженості в цій зоні 3 метою задоволення власних економічних i територіальних інтересів);

енергетична залежність (ціллю пропаганди може бути дискредитація України як надійного транзитера енергоносіїв);

неспроможність держави протистояти збройній агресії РФ (залучення військових, політичних експертів для висвітлення невтішних прогнозів стосовно України).

Загрози в інформаційній сфері та кібернетичному просторі визначаються як найбільш небезпечніші для будь-якої з держав в умовах гібридної агресії Росії проти України.

В найближчій перспективі серед загроз основними визначені такі, що пов'язані із зовнішньою політикою РФ:

експансія РФ поблизу кордонів;

конфлікти (зокрема, призупинені) у Чорноморському регіоні;

залежність енергетичної безпеки від РФ.

Перспективним напрямом подальших наукових досліджень може бути завдання з удосконалення заходів протидії зовнішнім інформаційним загрозам України 3 огляду на концепції забезпечення НБ провідних держав світу.

kibernetichna bezpeka rol-

ta mistse $\mathrm{v}$ uslovyyakh hibridnoyi Viyny.pdf. 4. Про рішення Ради національної безпеки і оборони України від 25 березня 2021 року "Про Стратегію воєнної безпеки України": Указ Президента України від 25 березня 2021 року № 121/2021. URL: https://zakon.rada.gov.ua/laws/show/121/2021\#n8.

5. Левченко О. В. Інформаційні загрози як різновид воєнних загроз державі / О.В.Левченко, Ю. І. Міхєєв // Наука і техніка Повітряних Сил Збройних Сил України. - 2018. - № 3(32). - С. 14-19. 6. Александров О. С. Нова 
стратегія національної безпеки Польщі - відповідь на європейські виклики та загрози сьогодення / О. С. Александров // Стратегічні пріоритети. - 2015. № 1 (34), - С. 131-138. 7. Златін О. Зовнішня політика й національна безпека Румунії у контексті агресії Росії проти України / О. Златін // Міжнародні зв'язки України: наукові пошуки і знахідки. - 2016. - Вип. 25. - С. 324 334. 8. Курас А. I. Національна безпека Білорусі: військово-політичні парадигми / А. I. Курас // наукові записки Інституту політичних i етнонаціональних досліджень ім. І. Ф. Кураса НАН України. - 2015. - Вип. 2. - С. 184-196. 9. Новий український Закон про освіту: чому законотворчий процес має значення. Юридична газета online. URL: https://yur-gazeta.com/golovna/noviyukrayinskiy-zakon-pro-osvitu-chomu-zakonotvorchiyproces-mae-znachennya.html. 10. Bezpečnostná stratégia Slovenskej Republiky 202. URL:

https://www.vlada.gov.sk/data/files/8048 bezpecnostnastrategia-sr-2021.pdf. 11. Новая Стратегия национальной безопасности Польши четко определяет угрозы. URL: https://www.polskieradio.pl/397/7839/Artykul/2515179/.

12. Котух Є. В. Основні підходи до забезпечення кібербезпеки: досвід країн вишеградської четвірки. 13. Проект Концепции национальной безопасности
Республики Молдова. URL: http://iep.md/analytic/0362Proekt-Koncepcii-nacionalnoj-bez.phtml. 14. Strategia naţională de apărare a ţării din 30 iunie 2020. 15. Указ Президента Республики Беларусь от 9.11.2010 № 575 “Об утверждении Концепции национальной безопасности Республики Беларусь”. URL: https://pravo.by/document $/$ ?guid $=2012$ \&oldDoc $=2010$ 276/2010-276(005-026).pdf\&oldDocPage=1. 16. Батька всіх врятує. План Лукашенка для Донбасу. URL: https://ua.korrespondent.net/ukraine/4028177-batka-vsikhvriatuie-plan-lukashenka-dlia-donbasu/. $\quad$ 17. Військові маневри “Захід-2017”: у НАТО дорікнули Росії та Білорусі за ухилення від прозорості. URL: https://www.unian.ua/world/2095069-viyskovi-manevrizahid-2017-u-nato-doriknuli-rosiji-ta-bilorusi-za-uhilennyavid-prozorosti.html. 18. Доктрина информационной безопасности Российской Федерации. URL: http://kremlin.ru/acts/bank/41460/page/1. 19. Указ Президента Российской Федерации от 31 декабря 2015 года № 683 "О Стратегии национальной безопасности Российской Федерации” URL: http://pravo.gov.ru/proxy/ips/?docbody $=\&$ link id $=0 \& n d=10$ 2385609\&firstDoc $=1$.

\title{
АНАЛИЗ ОСНОВНЫХ УГРОЗ НАЦИОНАЛЬНОЙ БЕЗОПАСНОСТИ ГОСУДАРСТВ-СОСЕДЕЙ УКРАИНЫ В УСЛОВИЯХ ГИБРИДНОЙ АГРЕССИИ РОССИИ
}

\author{
Александр Витальевич Левченко (доктор военных наук, профессор) \\ Дмитрий Леонидович Федорчук (кандидат технических наук) \\ Юрий Иванович Михеев (кандидат технических наук)
}

Житомирський военный институт имени С.П. Корольова, Житомир, Украина

В статье рассматривается концепция и суть угроз национальной безопасности стран, которые граничат с Украиной, вызванных гибридной агрессией России. Анализируются нормативные правовые акты, определяющчие возможные информационные угрозы Украине и странам-соседям: Польще, Словакии, Румьлнии, Молдове, Венгрии, Беларуси. Основное внимание уделяется реальным и потенциальным угрозам национальной безопасности государства в информационной сфере, а именно попытке манипулирования общественным сознанием, в частности путем распространения пропагандистских сообщений, ложной, неполной или предвзятой информации. Рассматривается Стратегия национальной безопасности Российской Федерации, которая определяет причины угроз национальной безопасности государства.

На основе анализа результатов мониторинга информаџионного пространства определяется основная целевая аудитория, выбранная спецслужбами Российской Федерации для распространения пропагандистских сообщений. В то же время основные иели пропаганды, распространяемой спеислужбами Российской Федерации в ходе антитеррористической операции и распространяемой в условиях операџии Объединенных сил в целях достижения стратегических целей страны-агрессора, а именно: дискредитация государства на международной арене, подрыв доверия к нему как к надежному экономическому и политическому партнеру; дискредитация военно-политического руководства государства, глав органов государственной власти всех уровней украинского общества; дестабилизация внутриполитической ситуачии в государстве; снижение морально-психологического состояния личного состава Вооруженных Сил Украины; информационная поддержка руководства временно оккупированных территорий, лидеров незаконно созданных вооруженных формирований, террористических организаций так называемых “ДНР” и “ЛНР”; демонстраџия военной мощчи Российской Федерации.

По результатам анализа заявленных национальных интересов и угроз национальной безопасности стран-соседей Украины выясняются особенности противостояния национальных интересов нашего государства: этническое разнообразие общества, эскалация напряженности в зоне территориальных интересов, агрессия Российской Федераџии.

Ключевые слова: гибридная агрессия, национальные интересы, национальная безопасность государства, пропаганда, Российская Федераџия, страны-соседи, мониторинг информационного пространства. 
ANALYSIS OF THE MAIN THREATS TO THE NATIONAL SECURITY OF THE JUDICIAL COUNTRIES OF UKRAINE DURING HYBRID AGGRESSION IN RUSSIA

\author{
Oleksandr Levchenko (Doctor of military sciences, professor) \\ Dmytro Fedorchuk (Candidate of technical sciences) \\ Yurii Mikhieiev (Candidate of technical sciences)
}

\title{
Zhytomyr Military Institute named after S.P. Korolev, Zhytomyr, Ukraine
}

The article examines the concept and the essence of threats to the national security of Ukraine's neighboring countries caused by Russia's hybrid aggression. Also analyzes the normative legal acts that determine possible information threats to Ukraine and neighboring countries: Poland, Slovakia, Romania, Moldova, Hungary, Belarus. The main attention is paid to real and potential threats to the national security of the state in the information sphere, namely the attempt to manipulate the public consciousness, in particular by disseminating propaganda messages, false, incomplete or biased information. The article also revues the National Security Strategy of the Russian Federation, which determines the causes of threats to the national security of the state.

Based on the analysis of the results of monitoring of the information space, the main target audience is chosen by the special services of the Russian Federation for the dissemination of propaganda messages. At the same time, the main goals of propaganda, which were disseminated by the special services of the Russian Federation during the anti-terrorist operation. His is still distributed in the conditions of the Joint Forces operation in order to achieve the strategic goals of the aggressor country, namely: discrediting the state on the international stage, losing trust as to reliable economic and political partner; discrediting the military and political leadership of the state, heads of state authorities at all levels among Ukrainian society; destabilization of the internal political situation in the state; reducing the moral and psychological state of the personnel of the Armed Forces of Ukraine; information support of the leadership of the temporarily occupied territories, leaders of illegally created armed groups, terrorist organizations of the so-called "DNR" and "LNR"; demonstration of military power of the Russian Federation.

The peculiarities of confrontation of the national interests of our state are found out according to the results of the analysis of the declared national interests and threats to the national security of the neighboring countries of Ukraine. Among them: ethnic diversity of society, escalation of tension in the zone of territorial interests, aggression of the Russian Federation.

Key words: hybrid aggression, national interests, national security of the state, propaganda, Russian Federation, neighboring countries, monitoring of information space.

\section{References}

1. Ghorbulin V. P., Kachynsjkyj A. B. (2005), Priorytetnistj nacionaljnykh interesiv u svitli Strateghiji nacionaljnoji bezpeky Ukrajiny // Strateghichna panorama. Problemy nacionaljnoji ta strateghichnoji bezpeky, №3. 2. Zakon Ukrainy "Pro osnovni zasady zabezpechennia kiberbezpeky Ukrainy" vid 05.10.2017 № 2163-VIII. 3. Ghryshhuk R. V. Informacijna ta kibernetychna bezpeka. 4. Pro rishennia Rady natsionalnoi bezpeky i oborony Ukrainy vid 25 bereznia 2021 roku "Pro Stratehiiu voiennoi bezpeky Ukrainy": Ukaz Prezydenta Ukrainy vid 25 bereznia 2021 roku № 121/2021. 5. Levchenko O. V. (2018), Informatsiini zahrozy yak riznovyd voiennykh zahroz derzhavi / O. V. Levchenko, Yu. I. Mikhieiev // Nauka i tekhnika Povitrianykh Syl Zbroinykh Syl Ukrainy. - 2018. - № 3(32). - S. 14-19. 6. Aleksandrov O. S. (2015), Nova stratehiia natsionalnoi bezpeky Polshchi - vidpovid na yevropeiski vyklyky ta zahrozy sohodennia / O. S. Aleksandrov // Stratehichni priorytety. - 2015. - № 1 (34). - S. 131-138. 7. Zlatin O. (2016), Zovnishnia polityka y natsionalna bezpeka Rumunii u konteksti ahresii Rosii proty Ukrainy / O. Zlatin // Mizhnarodni zviazky Ukrainy: naukovi poshuky i znakhidky. - 2016. - Vyp. 25. - S. 324-334. 8. Kuras A. I. (2015), Natsionalna bezpeka Bilorusi: viiskovo-politychni paradyhmy / A. I. Kuras // naukovi zapysky Instytutu politychnykh i etnonatsionalnykh doslidzhen im. I. F. Kurasa NAN Ukrainy. - 2015. - Vyp. 2. - S. 184-196. 9. Novyi ukrainskyi Zakon pro osvitu: chomu zakonotvorchyi protses maie znachennia. 10. Security strategy of the Slovak Republic 2021. 11. Novaya Strategiya nacional'noj bezopasnosti Pol'shi chetko opredelyaet ugrozy. 12. Kotukh Ye. V. Osnovni pidkhody do zabezpechennia kiberbezpeky: dosvid krain vyshehradskoi chetvirky. 13. Proekt Koncepcii nacional'noj bezopasnosti Respubliki Moldova. 14. National heating strategy from June 30, 2020. 15. Ukaz Prezidenta Respubliki Belarus' ot 9.11.2010 № 575 "Ob utverzhdenii Koncepcii nacional'noj bezopasnosti Respubliki Belarus". Nacional'nyj pravovoj Internet-portal Respubliki Belarus. 16. Batka vsikh vriatuie. Plan Lukashenka dlia Donbasu. Portal "Korrespondent.net" / Polityka. 17. Viiskovi manevry "Zakhid-2017": u NATO doriknuly Rosii ta Bilorusi za ukhylennia vid prozorosti. Informatsiine ahentstvo "UNIAN". 18. Doktrina informacionnoj bezopasnosti Rossijskoj Federacii. 19. Ukaz Prezidenta Rossijskoj Federacii ot 31 dekabrya 2015 goda № 683 "O Strategii nacional'noj bezopasnosti Rossijskoj Federacii”. 